KS. JERZY ADAMCZYK* - RADOM

\title{
BIBLIOTEKA WYŻSZEGO SEMINARIUM DUCHOWNEGO W ASPEKCIE PRAWNYM
}

\section{Wstęp}

Według Kodeksu Prawa Kanonicznego z 1983 r. droga do kapłaństwa wiedzie poprzez wyższe seminarium duchowne, bowiem ,młodzieńcy, zamierzający dojść do kapłaństwa, powinni dla otrzymania odpowiedniej formacji duchowej oraz przygotowania się do właściwych im obowiązków kształcić się w wyższym seminarium przez cały okres formacji, albo - gdy zdaniem biskupa diecezjalnego wymagają tego okoliczności - przynajmniej przez cztery lata"1. Konieczność wyższego seminarium duchownego dla formacji kapłańskiej wyakcentował Sobór Watykański II stwierdzając: „,dla formacji kapłanów konieczne są wyższe seminaria. Kształcenie w nich alumnów powinno w całości zmierzać do tego, by stawali się oni prawdziwymi duszpasterzami na wzór Pana naszego Jezusa Chrystusa, Nauczyciela, Kapłana i Pasterza"2.

Wyższe seminarium duchowne jest kościelnym zakładem naukowym o profilu filozoficzno-teologicznym, w którym kształcą się i wychowują przyszli prezbiterzy. Seminarium jest niezbędnie potrzebne dla przygotowania kandydatów do kapłaństwa. Jest ono doskonałym miejscem formacji, normalnym środowiskiem, także w sensie materialnym, prawdziwym domem formacyjnym dla kandydatów do kapłaństwa, zwyczajnym miejscem zamieszkania i nauki ${ }^{3}$.

W seminarium dokonuje się kształcenie alumnów na przyszłych duszpasterzy. Obejmuje ono nauczanie i uczenie się oraz zabiegi wychowawcze podejmowane

* Ks. Jerzy Adamczyk - dr hab. prawa kanonicznego, profesor Instytutu Teologicznego UKSW w Radomiu, e-mail: ksjerzyad@wp.pl

${ }^{1}$ Kan. $235 \S 1$.

${ }^{2}$ Concilium Oecumenicum Vaticanum II, Decretum de Institutione sacerdotali Optatam Totius, (28 octobris 1965), nr 4, „Acta Apostolicae Sedis” (dalej: AAS), 58 (1966) s. 713-727, tekst polski: Sobór Watykański II, Konstytucje, dekrety, deklaracje. Tekst polski. Nowe tlumaczenie, Poznań 2002, s. 288-301.

${ }^{3}$ Por. Ioannes Paulus PP. II, Adhortatio Apostolica Postsynodalis: Pastores dabo vobis (dalej: PDV) (25 marti 1992), nr 60, „Acta Apostolicae Sedis”, 84 (1992), s. 657-804. 
przez seminaryjnych formatorów. Alumn w wyniku kształcenia winien zdobyć wiadomości, umiejętności, kompetencje, określone cnoty, pożyteczne postawy i zainteresowania niezbędne do nauczania, uświęcania i kierowania ludem Bożym ${ }^{4}$.

Istotnym czynnikiem w procesie kształcenia przyszłych prezbiterów jest biblioteka seminaryjna przystosowana do potrzeb naszych czasów, zaopatrzona w dzieła różnego rodzaju, głównie o charakterze religijnym i społecznym ${ }^{5}$.

Przedmiotem naszego zainteresowania będzie zagadnienie biblioteki wyższego seminarium duchownego $\mathrm{w}$ aspekcie prawa kanonicznego. Najpierw uwaga zostanie zwrócona na potrzebę istnienia biblioteki seminaryjnej, z kolei zostanie naświetlona kwestia księgozbioru i infrastruktury tejże biblioteki, na koniec zostanie omówione zagadnienie organizacji tejże biblioteki.

\section{Potrzeba istnienia biblioteki seminaryjnej}

Do pełnienia posługi kapłańskiej alumni mają przygotować się poprzez odpowiednią formację intelektualną. Formacja ta jest jednym $\mathrm{z}$ istotnych wymiarów kształcenia w wyższym seminarium duchownym. Jest ona głęboko związana $z$ formacją ludzką oraz duchową, stanowi ich niezbędny element ${ }^{6}$. Omawiane kształcenie znajduje konkretne uzasadnienie w samej naturze posługi kapłańskiej i jest dziś szczególnie naglące ze względu na wyzwania „nowej ewangelizacji”. Kandydaci do kapłaństwa i prezbiterzy muszą przywiązywać wielką wagę do formacji intelektualnej w procesie wychowania i w działalności duszpasterskiej, jako że dla zbawienia braci i sióstr powinni szukać głębszego poznania Bożych tajemnic. Również obecna sytuacja cechująca się obojętnością religijną i powszechną niewiarą $\mathrm{w}$ realną zdolność rozumu do poznania obiektywnej i uniwersalnej prawdy, zdecydowanie domaga się wysokiego poziomu formacji intelektualnej, to jest takiego, który uzdolni kapłanów do głoszenia, właśnie w tego rodzaju sytuacji, niezmiennej Ewangelii Chrystusowej i do ukazywania jej jako wiarygodnej wobec słusznych wymagań ludzkiego rozumu?

$\mathrm{Na}$ formację intelektualną składa się wykształcenie doktrynalne, czyli specjalne, ściśle związane z pełnieniem misji kapłańskiej, oraz wykształcenie ogólne, które sprzyja opanowaniu wiadomości i sprawności niezbędnych każdemu współczesnemu człowiekowi, niezależnie od wykonywanego zawodu. Formacja intelektualna w ścisłym znaczeniu, stanowiąc wewnętrznie skoordynowany system, dostarcza nie tylko uporządkowanej wiedzy, lecz także motywów postępowania poprzez świadome i celowe oddziaływanie na osobowość studiujących ${ }^{8}$.

\footnotetext{
${ }^{4}$ Por. J. Szpet, Dydaktyka katechezy, Poznań 1999, s. 321.

${ }^{5}$ Por. Pius PP. XII, Adhortatio Apostolica Menti Nostrae (23 septembris 1950), parte III, AAS, 42 (1950), s. 657-702.

${ }^{6}$ Por. PDV, nr 51.

${ }^{7}$ Por. Sacra Congregazione per L'educazione Cattolica, Ratio fundamentalis institutionis sacerdotalis (6 ianuarii 1970 r.), nr 59, AAS, 62 (1970) s. 321-384, editio apparata post Codicem iuris canonici promulgatum (19 marzo 1985), Typis Polyglottis Vaticanis 1985.

${ }^{8}$ Por. T. Pawluk, Prawo kanoniczne wedtug Kodeksu Jana Pawła II. Lud Boży jego nauczanie i uświęcanie, t. 2, Olsztyn 1986, s. 68-69.
} 
Kodeks Prawa Kanonicznego z 1983 r. poleca, aby seminarzyści kształcili się w zakresie kultury humanistycznej, która winna stanowić podstawę ich formacji pastoralnej. W szczególności należy uczyć ich języków: ojczystego, łacińskiego, a także języków obcych ${ }^{9}$. Winni następnie odbyć kształcenie filozoficzne, które ma się oprzeć na wiecznie trwałym dziedzictwie filozoficznym, uwzględniającym również współczesne badania filozoficzne ${ }^{10}$, szczególną uwagę trzeba zwrócić na filozofię systematyczną ze wszystkimi jej działami, historię filozofii ${ }^{11}$ czy bioetykę ${ }^{12}$.W seminarium należy także wykładać nauki pokrewne, jakimi są nauki przyrodnicze i matematyczne $\mathrm{w}$ zakresie zagadnień związanych $\mathrm{z}$ filozofią ${ }^{13}$.

Klerycy powinni następnie uczestniczyć w wykładach dyscyplin teologicznych w ich różnych aspektach: ekumenicznym, czy misyjnym, jak również odbyć kształcenie teologiczne, na które składa się: studium Pisma św. ${ }^{14}$, teologii dogmatycznej, teologii moralnej i pastoralnej, prawa kanonicznego, liturgii, historii Kościoła oraz innych dyscyplin, pomocniczych i specjalnych, zgodnie z przepisami programu przygotowania do kapłaństwa ${ }^{15}$. Należy także wykładać katolicka naukę społeczną ${ }^{16}$.

Pozostaje czymś oczywistym, że skoro alumni mają otrzymać obszerną i solidną znajomość nauk świętych tak, by opierając się na nich i karmiąc nimi swoją wiarę, mogli głosić naukę Ewangelii współczesnym sobie ludziom, skoro „W ustalonych momentach alumni powinni zdawać sprawę z postępu w studiach przez kolokwia, pisemne opracowania i egzaminy"17, a profesorowie rozwijać się na polu nauki, to biblioteka seminaryjna jawi się jako konieczny czynnik formacji intelektualnej, jako nieodzowna pomoc w studium i pogłębianiu koniecznej wiedzy. Stąd redaktorzy Ratio fundamentalis institutionis sacerdotalis stwierdzają kategorycznie: „narzędziem koniecznym dla pracy naukowej profesorów i dla studiów alumnów jest biblioteka. W każdym seminarium winien ją prowadzić z wielką starannością odpowiednio do tego przygotowany bibliotekarz"18. Natomiast okólnik Le biblioteche ecclesiastiche nella missione della Chiesa zwraca uwagę na znaczenie, ,jakie ma korzystanie z biblioteki przez alumnów podczas

${ }^{9}$ Por. kan. 249.

${ }^{10}$ Por. kan. 251.

${ }^{11}$ Ratio fundamentalis institutionis sacerdotalis, $\mathrm{nr}$ 71-72.

${ }^{12}$ Congregazione per l'Educazione Cattolica (dei Seminari e degli Istituti di Studi), Direttive sulla formazione dei seminaristi circa i problemi relativi al matrimonio e alla famiglia (19 marzo 1995), nr 23, Bologna 1995, tekst polski: Kongregacja ds. Wychowania Katolickiego, Wskazania dla formacji alumnów dotyczace zagadnień matżeństwa i rodziny, Warszawa 2008.

${ }^{13}$ Por. tamże, $\mathrm{nr} 73$.

${ }^{14}$ Por. kan. $252 \S 1$.

${ }^{15}$ Por. kan. $252 \S 3$; por. Ratio fundamentalis institutionis sacerdotalis, $\mathrm{nr}$ 76-80.

${ }^{16}$ Por. Direttive sulla formazione dei seminaristi circa i problemi relativi al matrimonio, $\mathrm{nr} 29$.

${ }^{17}$ Ratio fundamentalis institutionis sacerdotalis, nr 93. „Mówiąc o seminarium (...) nie wolno pominąć faktu, że wspólnota ta ma charakter wyższej uczelni”. Zasady formacji kapłańskiej w Polsce, Częstochowa 1999, $\mathrm{nr} 87$.

${ }^{18} \mathrm{Nr}$ 92; por. IV Synod Diecezji Tarnowskiej. Ad imaginem ecclesiae universalis, Tarnów 1990, statut 461, s. 201. 
ich studiów teologicznych i filozoficznych"19. O konieczności istnienia bibliotek seminariów duchownych wypowiada się wprost Schematipo di regolamento delle biblioteche ecclesiastiche italiane zatwierdzony przez Konferencję Episkopatu Włoch $^{20}$. Przepisy Konferencji Episkopatu Włoch La formazione dei presbiteri nella Chiesa Italiana. Orientamenti e norme per i seminari expressis verbis stanowią, że struktura i funkcjonowanie studiów teologicznych muszą być uregulowane przepisami zatwierdzonymi przez biskupa albo, w przypadku seminariów międzydiecezjalnych czy regionalnych, przez zainteresowanych biskupów, w którym muszą dokładnie być określone normy dotyczące m.in. bibliotek ${ }^{21}$, jak również to, że seminaria powinny być wyposażone w biblioteki zaktualizowane i wyposażone w niezbędne urządzenia informatyczne tak, by odpowiadały na potrzeby nauczających i studentów ${ }^{22}$. Podobnie wypowiada się dyrektorium La formación para el ministerio presbiteral Konferencji Episkopatu Hiszpanii, gdzie prawodawca domaga się, aby w seminariach i ośrodkach studiów kościelnych istniały dobrze wyposażone specjalistyczne biblioteki, będące narzędziami dla studiów teologicznych, nauki języków klasycznych i nowożytnych ${ }^{23}$.

Dyrektorium Zasady formacji kapłańskiej w Polsce mówiąc o konieczności biblioteki seminaryjnej zawiera następujący zapis: „ważnym narzędziem pracy naukowej tak dla profesorów, jak i alumnów są biblioteka i czytelnia. Mają one być należycie urządzone, łatwo dostępne i stale uzupełniane ${ }^{24}$.

Pośrednio o omawianych bibliotekach wypowiada się konstytucja apostolska Pastor Bonus, gdzie czytamy, że Papieska Komisja dla Strzeżenia Dziedzictwa Artystyczno-Historycznego „po uzgodnieniu sprawy z Kongregacją Seminariów i Studiów oraz z Kongregacją do Spraw Kultu Bożego i Dyscypliny Sakramentów zabiega o to, ażeby Lud Boży miał coraz większą świadomość wagi i konieczności strzeżenia dziedzictwa historyczno-artystycznego Kościoła" 25 , jak również okólnik La formazione dei futuri presbiteri all'attenzione verso i beni culturali

${ }^{19}$ Pontificia Commissione per i Beni Culturali della Chiesa, Lettera circolare Le biblioteche ecclesiastiche nella missione della Chiesa (19 marzo 1994), nr 4.6; Enchiridion dei Beni Culturali della Chiesa. Documenti ufficiali della Pontificia Commissione per i Beni Culturali della Chiesa, Edizioni Dehoniane, Bologna 2002, s. 201-219, tekst polski: „Fides. Biuletyn bibliotek kościelnych", 1-2 (1996) s. 31-46.

${ }^{20}$ Associazione dei Bibliotecari Ecclesiastici Italiani, Schema-tipo di regolamento delle biblioteche ecclesiastiche italiane approvato dalla CEI, Proemio, „Bollettino di informazione”, 21 (2002) z. 3, s. 10-19.

${ }^{21}$ Conferenza Episcopale Italiana, La formazione dei presbiteri nella Chiesa Italiana. Orientamenti e norme per i seminari. Terza edizione, nr 132, „Notiziario della Conferenza Episcopale Italiana", 40 (2012) nr 10, s. 296-433.

${ }^{22}$ Tamże, nr 140.

${ }^{23}$ Conferencia Episcopal Españoña, La formación para el ministerio presbiteral. Plan de formación sacerdotal para los Seminarios Mayores (30 mayo 1996), Madrid 1996, nr 114.

${ }^{24}$ Zasady formacji kaptańskiej w Polsce, nr 147; por. Pierwszy Synod Diecezji Kaliskiej 20072009. Prawo diecezjalne Kościoła Kaliskiego, Kalisz 2009, Aneks 10, Statuty Wyższego Seminarium Duchownego Diecezji Kaliskiej, art. 40, nr 1, s. 205.

${ }^{25}$ Ioannes Paulus P.P. II, Constitutio Apostolica Pastor Bonus, (28 iulii 1988), art. 103, AAS, 80 (1988) s. 841-912. 
della Chiesa Papieskiej Komisji dla Strzeżenia Dziedzictwa Artystyczno-Historycznego: „niektóre Episkopaty narodowe, opracowały Normy dla własnych seminariów, w których przyjęły to zaproszenie sugerując zaplanowanie wykładów, w których w sposób pogłębiony i systematyczny będzie się brało pod uwagę, historię i zasady sztuki sakralnej, archeologii chrześcijańskiej, archiwistyki, bibliotekarstwa"26.

\section{Księgozbiór i infrastruktura biblioteki wyższego seminarium duchownego}

Biblioteka seminarium duchownego należy do kategorii bibliotek kościelnych, czyli ,jest to uporządkowany zbiór rękopisów, druków lub opracowań i innych środków, mający na celu przekazywanie tekstów i obrazów, będący w posiadaniu instytucji aprobowanych albo erygowanych w systemie kanonicznym"27, w tym przypadku wyższego seminarium duchownego.

Biblioteka to przede wszystkim księgozbiór, szerzej materiały biblioteczne. Gdy idzie o rodzaj tych materiałów, Zofia Gaca-Dąbrowska zaznacza, że w skład zbiorów wchodzą przede wszystkim dokumenty tekstowe, takie jak: książki, czasopisma, rękopisy, druki ulotne, normy, patenty, literatura firmowa. Ponadto na zbiory składają się zapisy dźwięku i druki - a więc nuty, płyty, taśmy dźwiękowe, afisze, ryciny, mapy, plany, globusy itd." ${ }^{28}$. Biblioteki kościelne, w tym seminaryjne, w różnej mierze zawierają podobne rodzaje zasobów.

Gdy idzie o zakres tematyczny zbiorów omawianej biblioteki, to należy powiedzieć, że w pierwszym rzędzie winny być to zbiory tyczące się nauk kościelnych (nauk świętych). Nauki kościelne to te, które są uprawiane na kościelnych uniwersytetach i wydziałach, instytutach wiedzy religijnej i seminariach duchownych. Do takich należą przede wszystkim teologia, prawo kanoniczne i filozofia chrześcijańska ${ }^{29}$. Według kan. 248 przekazywane kształcenie naukowe w seminarium ma sprawić, by alumni, wraz z ogólną kulturą odpowiadającą potrzebom miejsca i czasu, otrzymali obszerną i solidną znajomość nauk świętych. Podobnie postanawiają redaktorzy Ratio fundamentalis institutionis sacerdotalis, gdzie czytamy: „celem formacji naukowej jest to, aby alumni razem z ogólną kulturą dostosowaną do potrzeb naszych czasów zdobyli szeroką i solidną wiedzę w zakresie nauk świętych ${ }^{30}$. Stąd jest zrozumiałe, że biblioteka seminaryjna będzie przede wszystkim zaopatrzona w zbiory dotyczące nauk świętych.

Biblioteka seminaryjna powinna posiadać dzieła z zakresu filozofii chrześcijańskiej, bowiem alumni winni poznać filozofię systematyczną ze wszystkimi jej

${ }^{26}$ Pontificia Commissione per i Beni Culturali della Chiesa, La formazione dei futuri presbiteri all'attenzione verso $i$ beni culturali della Chiesa (Ai vescovi diocesani) (15 ottobre 1992), $\mathrm{nr} 22$, „Notitiae”, 28 (1992) s. 714-731; por. nr 24, 26

${ }^{27}$ Schema-tipo di regolamento delle biblioteche ecclesiastiche italiane approvato dalla CEI, art. 1, nr 1. Biblioteka seminaryjna należy do dóbr doczesnych Kościoła w myśl kan. $1257 \S 1$.

${ }^{28}$ Z. Gaca-Dąbrowska, Biblioteka, w: Wielka Encyklopedia PWN, t. 4, Warszawa 2001, s. 12.

${ }^{29}$ Por. Pawluk, Prawo kanoniczne wedtug Kodeksu Jana Pawła II, t. 2, s. 50.

${ }^{30} \mathrm{Nr} 59$. 
działami ${ }^{31}$, historię filozofii ${ }^{32}$, historię filozofii współczesnej ${ }^{33}$, wstęp do filozofii, metafizykę, filozofię przyrody, teorię poznania, etykę, ogólną metodologię nauk, logikę, filozofię $\mathrm{Boga}^{34}$, filozofię religii ${ }^{35}$, filozofię nauki ${ }^{36}$, antropologię filozoficzną, fenomenologię ${ }^{37}$, czy bioetykę ${ }^{38}$. Omawiany księgozbiór ma zawierać także pomoce z zakresu nauk pokrewnych filozofii, jakimi są nauki przyrodnicze i matematyczne ${ }^{39}$, psychologia ogólna i psychologia religii ${ }^{40}$, psychologia ogólna, rozwojowa, pastoralna, pedagogika $\mathrm{z}$ dydaktyką ${ }^{41}$, socjologia ogólna i socjologia religii, czy historia religii ${ }^{42}$.

Obok kształcenia filozoficznego przyszli kapłani winni studiować nauki teologiczne, przez co winni poznać całą doktrynę katolicką opartą na Objawieniu ${ }^{43}$. Stąd biblioteka winna posiadać dzieła z zakresu biblistyki ${ }^{44}$, teologii dogmatycznej, teologii moralnej i pastoralnej, prawa kanonicznego, liturgii, historii Kościoła oraz innych dyscyplin, pomocniczych i specjalnych, zgodnie z przepisami programu przygotowania do kapłaństwa ${ }^{45}$.

Niewątpliwie w omawianej bibliotece powinny być materiały (publikacje) dotyczące własnego Kościoła partykularnego, jak również odpisy różnych wydań albo przedruki dzieł autorów związanych $\mathrm{z}$ właścicielem księgozbioru (w tym przypadku z danym Kościołem partykularnym $)^{46}$.

Ponieważ prawodawca kodeksowy poleca, aby alumni nauczyli się dokładnie języka ojczystego, lecz także by dobrze znali język łaciński oraz posiadali wystarczającą znajomość języków obcych, których umiejętność wyda się konieczna lub pożyteczna do ich formacji, albo do wykonywania pasterskiej posługi należy

${ }^{31}$ Por. Ratio fundamentalis institutionis sacerdotalis, $\mathrm{nr} 71$; por. kan. 251.

${ }^{32}$ Por. Ratio fundamentalis institutionis sacerdotalis, nr 72; zob. kan. 251.

${ }^{33}$ Conferenza Episcopale Italiana, La formazione dei presbiteri nella Chiesa Italiana, cap. IV, nr II, 1 A, s. 392.

${ }^{34}$ Por. Zasady formacji kapłańskiej w Polsce, s. 139.

${ }^{35}$ Conferenza Episcopale Italiana, La formazione dei presbiteri nella Chiesa Italiana, cap. IV, nr II, 1 D, s. 393.

${ }^{36}$ Conferencia Episcopal Españoña, La formación para el ministerio presbiteral. Plan de formación sacerdotal para los Seminarios Mayores. Apéndice. Plan de estudios del seminario mayor, $\mathrm{nr} 7$.

${ }^{37}$ Tamże, nr 7.

${ }^{38}$ Por. Direttive sulla formazione dei seminaristi circa i problemi relativi al matrimonio, $\mathrm{nr} 21$.

${ }^{39}$ Por. Ratio fundamentalis institutionis sacerdotalis, $\mathrm{nr} 73$.

${ }^{40}$ Conferencia Episcopal Españoña, La formación para el ministerio presbiteral. Plan de formación sacerdotal para los Seminarios Mayores. Apéndice. Plan de estudios del seminario mayor, nr 7.

${ }^{41}$ Zasady formacji kapłańskiej w Polsce, s. 142.

${ }^{42}$ Conferencia Episcopal Españoña, La formación para el ministerio presbiteral. Plan de formación sacerdotal para los Seminarios Mayores. Apéndice. Plan de estudios del seminario mayor, $\mathrm{nr} 7$.

${ }^{43}$ Por. kan. $252 \S 1$.

${ }^{44}$ Zob. kan. $252 \S 2$.

${ }^{45}$ Zob. kan. 252 \& 3.

${ }^{46}$ Schema-tipo di regolamento, art. 12, nr 2; por. Le biblioteche ecclesiastiche, $\mathrm{nr}$ 4. 6. 
sądzić, że w księgozbiorze seminaryjnym powinny znajdować się różnego rodzaju słowniki i książki, czy inne materiały konieczne do nauki wspomnianych języków ${ }^{47}$.

Biblioteka seminaryjna to nie tylko księgozbiór, ale również cała infrastruktura mająca służyć funkcjonowaniu biblioteki. W miarę możliwości w obrębie biblioteki powinny być: pomieszczenia, w których przechowywany jest zasób biblioteczny (magazyn), osobna sala studium i ewentualnie konsultacji (czytelnia), pomieszczenia i pracownie dla personelu bibliotecznego oraz dla wykonywania reprodukcji, pomieszczenie dla działu dubletów oraz wypożyczalnia ${ }^{48}$. Najcenniejsze materiały należy przechowywać w bezpiecznych szafach ${ }^{49}$.

Nadto biblioteka seminaryjna powinna posiadać odpowiednie urządzenia umożliwiające zachowanie księgozbioru i łatwość w korzystaniu z niego. Przede wszystkim ma mieć właściwie sporządzone katalogi (,papierowe” i komputerowe). Teksty przechowywane w bibliotece powinny być skatalogowane według kryterium, które ułatwi ich odszukanie i będzie sprzyjać wymianie informacji bibliograficznych z innymi bibliotekami, przede wszystkim z kościelnymi ${ }^{50}$. Katalogi należy stale aktualizować w celu ułatwienia zarządzania materiałem bibliotecznym i badań ${ }^{51}$.

W bibliotece winien znajdować się odpowiedni sprzęt komputerowy, urządzenia do przeglądania mikrofilmów, czy do sporządzania reprodukcji ${ }^{52}$.

Warto dodać, że w bibliotece seminaryjnej, podobnie jak i w każdej nowoczesnej bibliotece, książki oraz inne dokumenty muszą być zabezpieczone przez systemy alarmowe i przeciwpożarowe, instalacja elektryczna winna być zgodna z obowiązującymi normami bezpieczeństwa, a w razie potrzeby należy zainstalować urządzenia służące do regulacji temperatury i wilgotności ${ }^{53}$.

Należy podkreślić, że okresowe odkurzanie, dezynfekcję i dezynsekcję pomieszczeń biblioteki powinno powierzać się wyspecjalizowanemu personelowi ${ }^{54}$.

${ }^{47}$ Por. kan. 249.

${ }^{48}$ Por. Schema-tipo di regolamento, art. 21; por. Regulamin Biblioteki Diecezjalnej w Sandomierzu, http://www.bdsandomierz.pl/index.php/regulamin (dostęp: 10.03.2013); por. Regulamin Biblioteki Wyższego Seminarium Duchownego w Koszalinie, A-B, www.bibliotekawsd.koszalin. opoka.org.pl/regulamin.htm (dostęp: 22.03.2013); por. I Synod Archidiecezji Biatostockiej, Statut Archidiecezjalnego Wyższego Seminarium Duchownego w Białymstoku, Białystok 2000, rozdz. VII, nr 2, s. 327.

${ }^{49}$ Schema-tipo di regolamento, art. 13, nr 3.

${ }^{50}$ Por. Schema-tipo di regolamento, cap. II, art. 6, nr 1, art. 9, nr 1; por. Regulamin Biblioteki Wyższego Seminarium Duchownego w Koszalinie, A, 5; zob. Le biblioteche ecclesiastiche, nr 4. 1.

${ }^{51}$ Por. Schema-tipo di regolamento, cap. II, art. 7, nr 2; por. por. IV Synod Diecezji Tarnowskiej, statut 461, s. 201; por. I Synod Diecezji Legnickiej (2007-2012), t. I, Statut Wyższego Seminarium Duchownego Diecezji Legnickiej, Legnica 2012, art. 68, nr 4, s. 163; por. I Synod Diecezji Łomżyńskiej, Łomża 2005, statut 70, s. 44.

${ }^{52}$ Por. Le biblioteche ecclesiastiche, nr 1. 4, 4. 1; por. Conferenza Episcopale Italiana, La formazione dei presbiteri nella Chiesa Italiana, cap. IV, nr 140, s. 383; por. Regulamin Biblioteki Diecezjalnej w Sandomierzu, § 14; por. Schema-tipo di regolamento, art. 9, $\mathrm{nr}$ 1, art. 14, nr 1.

${ }^{53}$ Por. Schema-tipo di regolamento, art. 13, $\mathrm{nr} 2$.

${ }^{54}$ Por. tamże, art. 15, nr 1. 


\section{Odpowiedzialni za bibliotekę seminaryjną oraz jej pracownicy}

Według Schema tipo di regolamento delle biblioteche ecclesiastiche italiane zatwierdzonego przez Konferencję Episkopatu Włoch biblioteka kościelna jest to uporządkowany zbiór rękopisów, druków, lub opracowań oraz innych środków mających na celu przekazywanie tekstów i obrazów, będący własnością instytucji lub osób prawnych erygowanych w systemie kanonicznym. Biblioteka wyższego seminarium duchownego jest biblioteką kościelną, ponieważ jest własnością wspomnianego seminarium, które, gdy zostanie erygowane, otrzymuje w Kościele osobowość prawną ${ }^{55}$. Można bowiem „erygować i utrzymywać wyższe seminarium duchowne tylko wtedy, gdy jest odpowiednia liczba alumnów i gdy są przełożeni właściwie przygotowani do swoich zadań oraz złączeni ze sobą braterską współpracą. (...) Ponadto konieczny jest stosowny gmach, biblioteka oraz inne urządzenia nieodzowne $\mathrm{z}$ racji rangi i charakteru instytucji" 56 .

Kodeks Prawa Kanonicznego przypisuje biskupowi diecezjalnemu, bądź zainteresowanym biskupom, w przypadku seminarium międzydiecezjalnego, nadrzędny zarząd i administrację seminarium w zakresie spraw duchowych i materialnych, jak również określa zakres odpowiedzialności biskupa za formację kandydatów do kapłaństwa ${ }^{57}$. Stąd wynika, że biskup diecezjalny jest także pierwszym odpowiedzialnym za istnienie i prawidłowe funkcjonowanie biblioteki seminaryjnej. To spostrzeżenie potwierdza Schema-tipo di regolamento delle biblioteche ecclesiastiche italiane, gdzie jest mowa o tym, że biblioteki seminariów są podległe biskupowi diecezjalnemu ${ }^{58}$. W Regulaminie Biblioteki Diecezjalnej w Sandomierzu widnieje następujące w tej kwestii postanowienie: „biblioteka Wyższego Seminarium Duchownego w Sandomierzu, nazywana w dalszym ciągu niniejszego regulaminu «Biblioteką», jest własnością osoby prawnej - Wyższego Seminarium Duchownego. Nie stanowi samodzielnej instytucji kościelnej, lecz podlega w pierwszym rzędzie Biskupowi Sandomierskiemu, następnie Rektorowi WSD i dyrektorowi Biblioteki" ${ }^{59}$, a w Statucie Biblioteki Diecezjalnej w Sandomierzu (w skład której wchodzi biblioteka seminaryjna) postanawia się: „nadzór nad Biblioteką sprawuje Biskup Diecezji Sandomierskiej, działając osobiście bądź przez swojego delegata" ${ }^{60}$.

${ }^{55}$ Por. kan. $238 \S 1$.

${ }^{56}$ Por. Ratio fundamentalis institutionis sacerdotalis, $\mathrm{nr} 21$.

${ }^{57}$ Por. kan. 259. „Spośród wszystkich instytucji diecezjalnych biskup winien uważać za najważniejszą seminarium, czyniąc je przedmiotem szczególnej i ciągłej opieki ze strony swojego urzędu pasterskiego". Congregaticio pro Episcopis, Direttorio per il ministero pastorale dei vescovi (22 febbraio 2004), nr 84, Città del Vaticano 2004, tekst polski: Kongregacja do spraw Biskupów, Dyrektorium o pasterskiej postudze biskupów „Apostolorum Successores” (dalej: AS) (22 lutego 2004 r.), Kielce 2005.

${ }^{58}$ Premio. Z kolei dokument Le biblioteche ecclesiastiche, pośrednio wskazuje, że biskup diecezjalny jest pierwszym odpowiedzialnym za biblioteki kościelne, w tym seminaryjne: „Oczywiście, biskupi i przełożeni generalni zgromadzeń zakonnych powinni w pierwszym rzędzie pragnąć odnowy swoich bibliotek". Nr 4.2.

${ }^{59}$ Regulamin Biblioteki Diecezjalnej w Sandomierzu, § 1.

${ }^{60}$ Statut Biblioteki Diecezjalnej w Sandomierzu, § 4. www.bdsandomierz.pl/index.php/statut (dostęp: 10.03.2013 r.) 
Wyrazem odpowiedzialności biskupa diecezjalnego lub, w przypadku seminariów międzydiecezjalnych czy regionalnych, zainteresowanych biskupów jest wydawanie norm odnośnie do wspomnianej instytucji naukowej. Normy te mogą być wydawane na synodzie diecezjalnym, czy prowincjalnym lub poza nimi. Na przykład statuty IV Synodu Diecezji Tarnowskiej zawierają taki zapis: „koniecznym zapleczem pracy naukowej profesorów i alumnów jest biblioteka seminaryjna, odpowiednio urządzona, łatwo dostępna i ciągle powiększana"61. Statuty wyższych seminariów duchownych zatwierdzone przez biskupów diecezjalnych, niejednokrotnie opublikowane w aneksach uchwał synodalnych, zawierają szereg przepisów tyczących się bibliotek seminaryjnych. Takie normy posiadają np. statuty seminariów duchownych w Legnicy ${ }^{62}$, Sosnowcu ${ }^{63}$, Kaliszu ${ }^{64}$, Rzeszowie ${ }^{65}$, czy też Białymstoku ${ }^{66}$.

Odpowiedzialność biskupa diecezjalnego za bibliotekę seminaryjną przejawia się w zatwierdzaniu statutów wyższych seminariów duchownych ${ }^{67}$, gdzie traktuje się expressis verbis o ich bibliotekach, czy odrębnych statutów i regulaminów tychże księgozbiorów ${ }^{68}$.

Według dyrektorium La formazione dei presbiteri nella Chiesa Italiana Konferencji Episkopatu Włoch struktura i funkcjonowanie studium teologii muszą być unormowane przez regulamin, zatwierdzony przez biskupa, lub w przypadku seminariów międzydiecezjalnych czy regionalnych przez zainteresowanych biskupów, w którym to regulaminie winny być dokładnie określone normy dotyczące kierownictwa, wykładowców, alumnów, programów poszczególnych dyscy-

${ }^{61}$ Statut 461, s. 201.

${ }^{62}$ I Synod Diecezji Legnickiej, t. I, Statut Wyższego Seminarium Duchownego Diecezji Legnickiej, art. 65-69, s. 162-163.

${ }^{63}$ I Synod Diecezji Sosnowieckiej, Prawo partykularne Kościoła Sosnowieckiego, Statut Wyższego Seminarium Duchownego Diecezji Sosnowieckiej w Krakowie, Sosnowiec 2005. art. 57-62, s. 167.

${ }^{64}$ Statuty Wyższego Seminarium Duchownego Diecezji Kaliskiej, art. 40-44, s. 205.

${ }^{65}$ Pierwszy Synod Diecezji Rzeszowskiej, Statut Wyższego Seminarium Duchownego w Rzeszowie, Rzeszów 2004, art. 65-68, s. 304.

${ }^{66}$ I Synod Archidiecezji Białostockiej, Statut Archidiecezjalnego Wyższego Seminarium Duchownego w Biatymstoku, rozdz. VII, s. 327-328.

${ }^{67}$ Np. Pierwszy Synod Diecezji Rzeszowskiej, Statut Wyższego Seminarium Duchownego w Rzeszowie, art. 65-68, s. 304; I Synod Diecezji Sosnowieckiej. Prawo partykularne Kościoła Sosnowieckiego, Statut Wyższego Seminarium Duchownego Diecezji Sosnowieckiej w Krakowie, art. 57-62, s. 167.

${ }^{68}$ Np. Statut Biblioteki Diecezjalnej w Sandomierzu § 2: ,,podstawę prawną funkcjonowania biblioteki stanowi dekret Biskupa Sandomierskiego Nr 1182/2006 z dnia 25 listopada 2006 roku”, czy tamże $\S 17$ : „Organizację wewnętrzną Biblioteki, a w szczególności zasady oraz formy jej działania określa Regulamin Biblioteki, opracowany przez Dyrektora Biblioteki, zatwierdzony przez Biskupa Sandomierskiego po zasięgnięciu opinii Rady Bibliotecznej”, jak również tamże § 22: „Statut Biblioteki nadaje Biskup Diecezjalny”; „Biblioteka Wyższego Seminarium Duchownego w Przemyślu posiada własny statut i regulamin, zatwierdzone przez biskupa diecezjalnego". Synod Archidiecezji Przemyskiej 1995-2000. Statuty i aneksy, Statut Wyższego Seminarium Duchownego w Przemyślu, Przemyśl 2000, rozdz. VII, art. 96. 
plin dla każdego rocznika alumnów, ilości godzin nauczania dla poszczególnych dyscyplin, egzaminów i bibliotek ${ }^{69}$.

Odpowiedzialność biskupa diecezjalnego za bibliotekę seminaryjną ukazuje się także w prawie do mianowania pracowników biblioteki. Według Ratio fundamentalis institutionis sacerdotalis ,zgodnie z miejscowym zwyczajem w każdym Seminarium winni być ludzie odpowiedzialni za kierowanie nim. Są to: Rektor, Wicerektor, Ojciec lub Ojcowie duchowni, Prefekt studiów, Kierownik praktyk duszpasterskich, Prefekt porządku życia wspólnego Seminarium, ekonom, bibliotekarz"70. Bibliotekarz należy więc do odpowiedzialnych za kierowanie seminarium, których „mianuje Biskup - jeżeli statuty Seminarium nie postanawiają inaczej po starannej konsultacji”71. Synod Diecezji Legnickiej postanawia, że „odpowiedzialnym wobec rektora za księgozbiór seminaryjny jest dyrektor Biblioteki, mianowany na wniosek rektora przez biskupa diecezjalnego"72. Prawodawca białostocki zarządza, że Archidiecezjalne Wyższe Seminarium Duchowne w Białymstoku ,podlega (...) bezpośrednio każdorazowemu Ordynariuszowi Archidiecezji, do którego zwłaszcza należy: a) powoływanie odpowiednich osób (DFK 5) na stanowiska moderatorów, wykładowców, prokuratora i dyrektora biblioteki"73. Z kolei I Synod Diecezji Sosnowieckiej postanawia, że „biblioteką seminaryjną zarządza dyrektor mianowany przez biskupa diecezjalnego na wniosek rektora"74, Synod Rzeszowski, stwierdza: ,na czele Biblioteki [seminaryjnej - J.A.] stoi Dyrektor mianowany przez Biskupa diecezjalnego" "75, Synod Przemyski: „Biblioteka Wyższego Seminarium Duchownego w Przemyślu (...) jest kierowana przez dyrektora mianowanego przez biskupa diecezjalnego"76.

Kolejnym odpowiedzialnym za bibliotekę seminaryjną jest rektor seminarium, który stoi na czele wspólnoty seminaryjnej i jest głównym współpracownikiem biskupa diecezjalnego oraz jego reprezentantem w kwestii kształcenia przyszłych prezbiterów. Winien on czuć się ściśle złączony z biskupem, którego jest przedstawicielem z tytułu swojego urzędu oraz szczerze i z przekonaniem współpracować $\mathrm{z}$ innymi odpowiedzialnymi za formację kleryków ${ }^{77}$. Rektora mianuje biskup diecezjalny ${ }^{78}$. Dyrektor biblioteki podlega rektorowi seminarium. Stąd

${ }^{69}$ Conferenza Episcopale Italiana, La formazione dei presbiteri nella Chiesa Italiana, nr 132, s. 393.

${ }^{70}$ Ratio fundamentalis institutionis sacerdotalis, $\mathrm{nr} 27$.

${ }^{71}$ Tamże, nr 28.

${ }^{72}$ I Synod Diecezji Legnickiej, t. I, Statut Wyższego Seminarium Duchownego Diecezji Legnickiej, art. 7, s. 162.

${ }^{73}$ I Synod Archidiecezji Białostockiej, Statut Archidiecezjalnego Wyższego Seminarium Duchownego w Białymstoku, rozdz. I, nr 4, s. 320.

${ }^{74}$ I Synod Diecezji Sosnowieckiej. Prawo partykularne Kościoła Sosnowieckiego, Statut Wyższego Seminarium Duchownego Diecezji Sosnowieckiej w Krakowie, art. 58, s. 167.

${ }^{75}$ Pierwszy Synod Diecezji Rzeszowskiej, Statut Wyższego Seminarium Duchownego w Rzeszowie, art. 66, s. 304.

${ }^{76}$ Synod Archidiecezji Przemyskiej 1995-2000. Statuty i aneksy, Statut Wyższego Seminarium Duchownego w Przemyślu, rozdz. VII, art. 95.

${ }^{77}$ Por. PDV, nr 66.

${ }^{78}$ Por. Ratio fundamentalis institutionis sacerdotalis, $\mathrm{nr}$ 27-28. 
Synod Legnicki przypomina, że „odpowiedzialnym wobec rektora za księgozbiór seminaryjny jest dyrektor Biblioteki, mianowany na wniosek rektora przez biskupa diecezjalnego"79. Według Regulaminu Biblioteki Diecezjalnej w Sandomierzu „Biblioteka Wyższego Seminarium Duchownego w Sandomierzu, nazywana w dalszym ciągu niniejszego regulaminu «Biblioteką», jest własnością osoby prawnej - Wyższego Seminarium Duchownego. Nie stanowi samodzielnej instytucji kościelnej, lecz podlega w pierwszym rzędzie Biskupowi Sandomierskiemu, następnie Rektorowi WSD i dyrektorowi Biblioteki" ". Synod Białostocki postanawia w tym względzie: ,na rektorze spoczywa troska o utrzymanie odpowiedniego poziomu naukowego w Seminarium. W związku z tym rektor: (...) dba o działalność biblioteki i kół naukowych" ". Synod Sosnowiecki stwierdza, że ,biblioteką seminaryjną zarządza dyrektor mianowany przez biskupa diecezjalnego na wniosek rektora, przed którym jest odpowiedzialny za bibliotekę" ${ }^{\text {" }}$.

Odpowiedzialność rektora za księgozbiór seminaryjny przejawia się m.in. w zatwierdzaniu przez niego własnego regulaminu biblioteki seminaryjnej ${ }^{83}$. Rektor jest też odpowiedzialny za budżet biblioteki ${ }^{84}$.

Ważny w omawianej kwestii jest przepis wyjęty z dokumentów I Synodu Diecezji Legnickiej: „,co roku, najpóźniej do 30 września, dyrektor Biblioteki przedkłada rektorowi, prócz sprawozdania o wykonaniu budżetu bibliotecznego za rok ubiegły i projektu budżetu na nowy rok akademicki, również dane, wykazy i zestawienia dotyczące stanu, działalności i potrzeb biblioteki seminaryjnej"85, jak również ,biblioteka może przyjmować dary i depozyty w zbiorach bibliotecznych oraz w ruchomościach związanych z jej działalnością. Jeżeli jednak do darów czy depozytów dołączone zostały warunki obciążające (np. jakiekolwiek zobowiązania natury duchowej lub materialnej), można je przyjąć jedynie za zgodą Rektora" ${ }^{\circ 6}$.

${ }^{79}$ I Synod Diecezji Legnickiej, t. I, Statut Wyższego Seminarium Duchownego Diecezji Legnickiej, art. $67 \S 1$, s. 162 .

${ }^{80}$ Regulamin Biblioteki Diecezjalnej w Sandomierzu, § 1. „Zależnie od aktualnych potrzeb i warunków, dyrektor Biblioteki w porozumieniu z Rektorem, tworzy lub likwiduje poszczególne działy", tamże, § 16 .

${ }^{81}$ I Synod Archidiecezji Białostockiej, Statut Archidiecezjalnego Wyższego Seminarium Duchownego w Biatymstoku, rozdz. II, 6 c), s. 321.

${ }^{82}$ I Synod Diecezji Sosnowieckiej. Prawo partykularne Kościoła Sosnowieckiego, Statut Wyższego Seminarium Duchownego Diecezji Sosnowieckiej w Krakowie, art. 58, s. 167.

${ }^{83}$ Por. I Synod Diecezji Legnickiej, t. I, Statut Wyższego Seminarium Duchownego Diecezji Legnickiej, art. 66, s. 162. „Biblioteka rządzi się normami Regulaminu, zatwierdzonego przez Rektora i Zarząd WSD”. Regulamin Biblioteki Diecezjalnej w Sandomierzu, § 1.

${ }^{84}$ Por. I Synod Diecezji Legnickiej, t. I, Statut Wyższego Seminarium Duchownego Diecezji Legnickiej, art. 69 § 1, s. 163. „Biblioteka prowadzi swą działalność w ramach budżetu zatwierdzonego co roku przez Rektora i Zarząd. Podstawę do zatwierdzenia budżetu i gospodarowania nim stanowi plan finansowy, opracowany i przedstawiony przez dyrektora Biblioteki w miesiącu styczniu nowego roku kalendarzowego. Rektor i Zarząd przez swych delegatów mają prawo kontroli realizacji preliminarza budżetowego Biblioteki”. Regulamin Biblioteki Diecezjalnej w Sandomierzu, § 1.

${ }^{85}$ Por. I Synod Diecezji Legnickiej, t. I, Statut Wyższego Seminarium Duchownego Diecezji Legnickiej, art. $69 \S 2$, s. 163.

${ }^{86}$ Regulamin Biblioteki Diecezjalnej w Sandomierzu, $§ 2$. 
Cenny dla omawianego zagadnienia jest przepis Regulaminu Biblioteki Diecezjalnej w Sandomierzu w myśl którego „,do dyrektora Biblioteki należy: przedstawianie Rektorowi corocznego sprawozdania z działalności Biblioteki"87.

Jednak bezpośrednim odpowiedzialnym i pierwszym pracownikiem biblioteki seminarium duchownego jest dyrektor biblioteki, czyli bibliotekarz.

„Zgodnie z miejscowym zwyczajem w każdym Seminarium winni być ludzie odpowiedzialni za kierowanie nim. Są to: Rektor, Wicerektor, Ojciec lub Ojcowie duchowni, Prefekt studiów, Kierownik praktyk duszpasterskich, Prefekt porządku życia wspólnego Seminarium, ekonom, bibliotekarz. Jasno powinny być określone ich funkcje, prawa i obowiązki oraz słuszne wynagrodzenie" 88 , jednak „w Seminarium o bardziej skromnych warunkach, obejmujących mniejszą liczbę alumnów, nie jest ściśle wymagane, aby do wyszczególnionych tu funkcji było przydzielonych tylu ludzi”"89. Z przytoczonych przepisów wyjętych z Ratio fundamentalis institutionis sacerdotalis wynika, że urząd bibliotekarza seminaryjnego jest obowiązkowy ${ }^{90}$, choć w niektórych okolicznościach może go pełnić osoba pełniąca inne zadanie $\mathrm{w}$ seminarium, np. jeden z profesorów. Jednakże, jeśli przepisy tyczące się biblioteki seminaryjnej nakazują, aby urząd bibliotekarza pełniła osoba przeznaczona tylko do wykonywania tej funkcji, to bibliotekarzem może być ktoś, kto nie ma innych obowiązków, jak tylko zarządzanie księgozbiorem seminaryjnym ${ }^{91}$.

Powstaje pytanie: czy dyrektorem biblioteki musi być tylko kapłan (prezbiter), czy może nim być diakon stały, zakonnik, czy świecki. Według Ratio fundamentalis institutionis sacerdotalis, ,zgodnie z miejscowym zwyczajem w każdym Seminarium winni być ludzie odpowiedzialni za kierowanie nim. Są to: Rektor, Wicerektor, Ojciec lub Ojcowie duchowni, Prefekt studiów, Kierownik praktyk duszpasterskich, Prefekt porządku życia wspólnego Seminarium, ekonom, bibliotekarz"92. Z wyliczonych funkcji seminaryjnych kapłanami powinni być: rektor ${ }^{93}$,

${ }^{87}$ Tamże, $\S 5$.

${ }^{88}$ Ratio fundamentalis institutionis sacerdotalis, $\mathrm{nr} 27$.

${ }^{89}$ Tamże.

90 „Narzędziem koniecznym dla pracy naukowej profesorów i dla studiów alumnów jest biblioteka. W każdym Seminarium winien ją prowadzić z wielką starannością odpowiednio do tego przygotowany bibliotekarz". Ratio fundamentalis institutionis sacerdotalis, $\mathrm{nr} 92$.

${ }^{91}$ Wskazania dotyczące przygotowania wychowawców w seminariach Kongregacji ds. Wychowania Katolickiego urząd bibliotekarza nazywają „,szczególną funkcją” pełnioną w seminarium. Congregazione per L'educazione Cattolica, Direttive Tra $i$ vari mezzi sulla preparazione degli educatori nei seminari (4 novembre 1993), nr 64, w: Enchiridion Vaticanum, t. 13, Bologna 1995, nr 1734-1775, tekst polski: Kongregacja ds. Wychowania Katolickiego, Wskazania dotyczace przygotowania wychowawców w seminariach, Rzym 1993.

${ }^{92}$ Ratio fundamentalis institutionis sacerdotalis, $\mathrm{nr} 27$.

93 „Biskup ze szczególną troską winien dobierać rektora seminarium spośród najlepszych kapłanów diecezji”. AS, nr 89. 
wicerektor ${ }^{94}$, ojciec duchowny ${ }^{95}$, prefekt studiów, kierownik praktyk duszpasterskich i prefekt porządku życia wspólnego seminarium ${ }^{96}$. Według Zasad formacji kapłańskiej $w$ Polsce przełożonych takich jak: rektor, wicerektor, wychowawcy (prefekci), ojcowie duchowni oraz dyrektor ds. administracyjnych ,mianuje biskup diecezjalny po uprzednim przekonsultowaniu ich kandydatury. Przełożeni powinni być wybierani starannie spośród kapłanów"97.

Gdy chodzi o profesorów wykładających przedmioty teologiczne, to „niech będą [nimi - J. A.] zazwyczaj kapłani”98, choć „w przypadkach szczególnych i zgodnie $z$ charakterem danej dyscypliny naukowej stanowisko profesora seminarium może zostać powierzone także świeckim - tym, którzy mają odpowiednie kompetencje oraz dają przykład autentycznego życia chrześcijańskiego" ${ }^{99}$. Normy prawne nie wypowiadają się na temat osób, które mogą być bibliotekarzami seminaryjnymi. Z powyższego wynika więc, że dyrektorem biblioteki może być zarówno prezbiter, diakon, zakonnik bez święceń lub laik ${ }^{100}$.

Tam gdzie przepisy partykularne domagają się, aby bibliotekarz był kapłanem, to należy tą funkcję powierzać wyłącznie prezbiterom.

Gdy idzie o mianowanie na urząd dyrektora omawianej biblioteki, to kompetentny jest $\mathrm{w}$ tej sprawie biskup diecezjalny, gdyż to on bądź zainteresowani biskupi, jeśli chodzi o seminarium międzydiecezjalne sprawuje nadrzędny zarząd i administrację seminarium w zakresie spraw duchowych i materialnych ${ }^{101}$.

Według Ratio fundamentalis institutionis sacerdotalis bibliotekarz należy do osób odpowiedzialnych za kierowanie seminarium, a wspomniane osoby, jeżeli statuty seminarium nie postanawiają inaczej, po starannej konsultacji mianuje biskup $^{102}$.

${ }^{94}$ „Biskup ze szczególną troską winien dobierać (...) przełożonych seminarium spośród najlepszych kapłanów diecezji wyróżniających się pobożnością i wiernością doktrynie, odpowiednim doświadczeniem i dużą gorliwością w duszpasterstwie oraz specjalnymi zdolnościami formacyjnymi i pedagogicznymi. Jeżeli ich nie posiada, prosi inne diecezje, bardziej zasobne w takich kapłanów”. AS, nr 89.

${ }^{95}$ Biskup ze szczególną troską winien dobierać (...) kierownika duchowego, (...) spośród najlepszych kapłanów diecezji wyróżniających się pobożnością i wiernością doktrynie. AS, nr 89.

96 „Biskup ze szczególną troską winien dobierać (...) przełożonych seminarium spośród najlepszych kapłanów". AS, nr 89.

${ }^{97}$ Zasady formacji kaptańskiej w Polsce, nr 104.

${ }^{98}$ Ratio fundamentalis institutionis sacerdotalis, nr 33. Sformułowanie „zazwyczaj kapłani” świadczy, że w określonych okolicznościach i z określonych przyczyn profesorami teologii mogą być osoby nie mające święceń prezbiteratu.

${ }^{99} \mathrm{AS}, \mathrm{nr} 89$.

${ }^{100}$ Pośrednio wskazuje na ten wniosek następujący tekst: „Wydaje się więc, że nadszedł czas, by konferencje biskupów opracowały na użytek pracowników bibliotek kościelnych «wytyczne dla bibliotek kościelnych», które ukazywałyby całej wspólnocie kościoła misję pasterską, którą bibliotekarze (księża, zakonnicy względnie świeccy) spełniają w rozprzestrzenieniu kultury chrześcijańskiej i w dialogu z innymi kulturami". Le biblioteche ecclesiastiche, $\mathrm{nr}$ 4. 7. Biblioteki seminaryjne są bibliotekami kościelnymi.

${ }^{101}$ Por. kan. 259.

102 Ratio fundamentalis institutionis sacerdotalis, nr 27-28; por. I Synod Diecezji Legnickiej, t. I, Statut Wyższego Seminarium Duchownego Diecezji Legnickiej, art. 7, s. 162. I Synod Archidie- 
Tak jak na każdy urząd kościelny, tak również na urząd bibliotekarza seminaryjnego może być powołany ten, kto posiada określone kwalifikacje. Zgodnie z kan. $149 \S 1$,ażeby urząd kościelny można komuś powierzyć, powinien on pozostawać we wspólnocie Kościoła i być zdatnym, czyli posiadać przymioty wymagane do tego urzędu prawem powszechnym, partykularnym lub fundacyjnym".

Niewątpliwie bibliotekarz winien mieć ogólne kwalifikacje podobne do przymiotów profesorów seminaryjnych ${ }^{103}$. Należy on bowiem do odpowiedzialnych za kierowanie seminarium ${ }^{104}$, pełniąc zarówno funkcje $\mathrm{w}$ dziedzinie formacji intelektualnej, jak i pedagogicznej ${ }^{105}$. Nie jest on tylko zatrudnionym pracownikiem, ale „również animatorem kultury, i tym samym winien on pośrednio ewangelizować wspólnotę kościelną, do której przynależy, oraz poszukiwać tych, co pragną pogłębić swoje wiadomości”'106. Stąd winien odznaczać się cnotą ${ }^{107}$, wyróżniać się pobożnością ${ }^{108}$, dawać alumnom przykład życia chrześcijańskiego lub kapłańskie$\mathrm{go}^{109}$, odznaczać się wiernością doktrynie ${ }^{110}$.

Oprócz przymiotów ogólnych, właściwych każdemu odpowiedzialnemu za kierowanie seminarium, bibliotekarz winien posiadać odpowiednie i specyficzne przygotowanie do kompetentnego wykonywania swojego urzędu ${ }^{111}$. „W każdym Seminarium winien prowadzić [bibliotekę - J.A.] z wielką starannością odpowiednio do tego przygotowany bibliotekarz"112. Według Wskazań dotyczacych przygotowania wychowawców $w$ seminariach ,jeśli chodzi o innych współpracowników - poza wicerektorem i prefektami, którzy powinni posiadać co najmniej solidną formację podstawową - wymagane jest zdobycie przygotowania «fachowego» do spełniania niektórych szczególnych funkcji np. bibliotekarza lub ekonoma. Dla tych i podobnych zadań zaleca się należyte ukierunkowanie zawo-

cezji Białostockiej, Statut Archidiecezjalnego Wyższego Seminarium Duchownego w Biatymstoku, rozdz. I, nr 4, s. 320; I Synod Diecezji Sosnowieckiej. Prawo partykularne Kościoła Sosnowieckiego, Statut Wyższego Seminarium Duchownego Diecezji Sosnowieckiej w Krakowie, art. 58, s. 167; Pierwszy Synod Diecezji Rzeszowskiej, Statut Wyższego Seminarium Duchownego w Rzeszowie, art. 66, s. 304; Synod Archidiecezji Przemyskiej 1995-2000. Statuty i aneksy, Statut Wyższego Seminarium Duchownego w Przemyślu, rozdz. VII, art. 95.

${ }^{103} \mathrm{~W}$ mniejszych seminariach jeden z profesorów może być jednocześnie bibliotekarzem. Por. Ratio fundamentalis institutionis sacerdotalis, $\mathrm{nr} 27$.

${ }^{104}$ Por. Ratio fundamentalis institutionis sacerdotalis, nr 27.

${ }^{105}$ „W wypełnianiu swojej funkcji niech się [profesorowie - J.A.] uważają rzeczywiście za wychowawców". Ratio fundamentalis institutionis sacerdotalis, $\mathrm{nr} 38$.

${ }^{106}$ Le biblioteche ecclesiastiche, $\mathrm{nr} 4.1$.

${ }^{107}$ Por. kan. $253 \S 1$.

${ }^{108}$ Por. AS, nr 89.

${ }^{109}$ Por. Ratio fundamentalis institutionis sacerdotalis, $\mathrm{nr} 33$.

${ }^{110}$ Por. AS, nr 89.

${ }^{111}$ Także w przypadku, gdy seminarium obejmuje mniejszą liczbę alumnów i funkcję bibliotekarza pełni osoba, która wykonuje także inny urząd w seminarium np. któryś z profesorów, to także winna posiadać odpowiednie kwalifikacje i przygotowanie do realizacji urzędu bibliotekarza. Por. Ratio fundamentalis institutionis sacerdotalis, $\mathrm{nr} 27$.

${ }^{112}$ Ratio fundamentalis institutionis sacerdotalis, $\mathrm{nr} 92$. 
dowe, nabyte podczas nauki w szkole lub na kursach specjalistycznych. Znaczenie biblioteki dla rzetelności i poziomu studiów, jak też delikatność i złożoność problemów administracyjnych wymagają, by funkcje te wykonywali prawdziwi fachowcy"113. Dyrektor biblioteki seminaryjnej, podobnie jak inni wychowawcy, powinien odznaczać się także uzdolnieniami pedagogicznymi ${ }^{114}$.

Jak wcześniej stwierdzono, każde seminarium duchowne winno mieć własna bibliotekę, co suponuje, że kierowanie nią jest powierzone określonej osobie, czyli dyrektorowi biblioteki. Jednakże w zasadzie wspomniany urzędnik seminaryjny nie jest w stanie samodzielnie wykonywać owocnie swoje zadania, stąd potrzebuje rozmaitych współpracowników, etatowych lub wolontariuszy ${ }^{115}$. Wprawdzie w niewielkich bibliotekach dyrektor, czy osoba, która oprócz kierowania księgozbiorem seminaryjnym pełni w seminarium inne funkcje, może jednak bez większych trudności sprostać zadaniom wynikającym z kierowania biblioteką ${ }^{116}$. Jednak, jak się wydaje, sytuacje takie są niezbyt częste.

Z zapisu Wskazań dotyczacych przygotowania wychowawców w seminariach Kongregacji ds. Wychowania Katolickiego, który brzmi: ,znaczenie biblioteki dla rzetelności i poziomu studiów, jak też delikatność i złożoność problemów administracyjnych wymagają, by funkcje te [m.in. bibliotekarza - J.A.] wykonywali prawdziwi fachowcy"117, wolno sądzić, że fachowe prowadzenie biblioteki wymaga zatrudnienia w tej instytucji poza dyrektorem także innych osób.

Wśród współpracowników bibliotekarza można wyróżnić pracowników etatowych i wolontariuszy.

Odnośnie do pierwszej kategorii zatrudnionych w bibliotece seminaryjnej wypowiada się I Synod Diecezji Legnickiej: „Dyrektor Biblioteki ma do pomocy świeckich pracowników Biblioteki"118, a Regulamin Biblioteki Diecezjalnej w Sandomierzu zawiera następujące postanowienie: „Personel Biblioteki stanowią: archiwista; bibliotekarz; pracownik" ${ }^{119}$. Prawodawcy mówią także o osobach dyżurujących w bibliotece i wypożyczalni, co może wskazywać właśnie na eta-

${ }^{113} \mathrm{Nr} 64$.

${ }^{114}$ Por. tamże, nr 35. Przepisy Konferencji Episkopatu Włoch La formazione dei presbiteri nella Chiesa Italiana. Orientamenti e norme per i seminari postanawiają, że zajęciom teoretycznym w seminarium winny towarzyszyć krótkie ćwiczenie, m. in. zwiedzanie biblioteki, co suponuje zaangażowanie bibliotekarza odznaczającego się przygotowaniem zawodowym i pedagogicznym. $\mathrm{Nr}$ 5, s. 390. Na przygotowanie zawodowe i pedagogiczne dyrektora biblioteki wskazuje następujący tekst: „dyrektor biblioteki winien szerzyć kulturę czytelniczą wśród alumnów oraz służyć pomocą pracownikom naukowo-dydaktycznym w Seminarium”. I Synod Archidiecezji Białostockiej, Statut Archidiecezjalnego Wyższego Seminarium Duchownego w Białymstoku, rozdz. VII, nr 5, s. 328.

115 „Wiadomo, że problemem większości bibliotek kościelnych jest cena nowych publikacji i koszt utrzymania samych bibliotek, wymagających pełnego i kompletnego, a więc stałego personelu". Le biblioteche ecclesiastiche, $\mathrm{nr}$ 4. 9.

${ }^{116}$ Por. Ratio fundamentalis institutionis sacerdotalis, $\mathrm{nr} 27$.

${ }^{117}$ Direttive Tra i vari mezzi, $\mathrm{nr} 64$.

${ }^{118}$ Art. 67 § 2, s. 162.

${ }^{119}$ Regulamin Biblioteki Diecezjalnej w Sandomierzu, $§ 7$. 
towych pracowników księgozbioru seminaryjnego ${ }^{120}$. Według Statutu Archidiecezjalnego Wyższego Seminarium Duchownego w Białymstoku ,dyrektor biblioteki w porozumieniu z rektorem może przyjąć do pomocy dodatkowych pracowników. Wskazane jest, aby to byli ludzie fachowi i uczciwi"121. Pośrednio o etatowych pracownikach książnicy seminaryjnej traktuje przepis z Pierwszego Synodu Diecezji Rzeszowskiej: „,poza ogólnym kierownictwem Biblioteki do zadań dyrektora należy: (...) Przedstawienie rektorowi wniosków o zatrudnieniu personelu Biblioteki oraz kierowanie jego pracą"122. Podobnie wypowiada się I Synod Diecezji Sosnowieckiej w następującej normie: „dyrektor biblioteki dobiera sobie za wiedzą i zgodą rektora Seminarium Duchownego personel pomocniczy"123.

Według Schema-tipo di regolamento delle biblioteche ecclesiastiche italiane zatwierdzonego przez Konferencję Episkopatu Włoch, w bibliotece kościelnej (w tym seminaryjnej), oprócz pracowników mających bezpośredni związek z zasobem bibliotecznym, można zatrudniać innych pracowników wykonujących funkcje stróżowania, ochrony księgozbioru i inne ${ }^{124}$.

Oprócz pracowników zatrudnionych na stałe (etatowych) wskazane jest, aby w bibliotece seminaryjnej pracowali wolontariusze, czyli pracownicy nieetatowi. Odnośnie do tej kategorii pracujących, na pierwszym miejscu będą to alumni seminarium - właściciela biblioteki. Według I Synodu Diecezji Sosnowieckiej ,do pomocy w obsłudze korzystających z biblioteki rektor, w porozumieniu z dyrektorem biblioteki, wyznacza stałe oficjum kleryków"125, natomiast I Synod Archidiecezji Białostockiej postanawia, że „,dyrektor biblioteki (...) może też dobrać sobie do pomocy alumnów"126, a I Synod Diecezji Legnickiej stwierdza, że „dyrektor Biblioteki ma do pomocy (...) dyżurujących alumnów”.127.

W bibliotekach seminaryjnych za zgodą odpowiedzialnych za nie, można także korzystać z pomocy innych (oprócz alumnów) wolontariuszy. Zgodnie z Schema-tipo di regolamento delle biblioteche ecclesiastiche italiane zatwierdzonym przez Konferencję Episkopatu Włoch, gdy okoliczności doradzają, w bibliotekach kościelnych (także seminaryjnych) można korzystać ze współpracy odpowiednio przygotowanego personelu wolontariuszy ${ }^{128}$.

${ }^{120}$ Zob. por. Regulamin Biblioteki Wyższego Seminarium Duchownego w Koszalinie, cz. A, nr. $4-5,10,12$.

${ }^{121}$ Rozdz. VII, nr 3, s. 328.

${ }^{122}$ Pierwszy Synod Diecezji Rzeszowskiej, Statut Wyższego Seminarium Duchownego w Rzeszowie, art. 67, $\mathrm{nr} 4$, s. 304.

${ }^{123}$ I Synod Diecezji Sosnowieckiej. Prawo partykularne Kościoła Sosnowieckiego, Statut Wyższego Seminarium Duchownego Diecezji Sosnowieckiej w Krakowie, art. 58, s. 167.

${ }^{124}$ Por. Schema-tipo di regolamento, cap. IV, art. 18, $\mathrm{nr} 1$.

${ }^{125}$ I Synod Diecezji Sosnowieckiej. Prawo partykularne Kościoła Sosnowieckiego, Statut Wyższego Seminarium Duchownego Diecezji Sosnowieckiej w Krakowie, art. 62, s. 167.

${ }^{126}$ I Synod Archidiecezji Białostockiej, Statut Archidiecezjalnego Wyższego Seminarium Duchownego w Bialymstoku, rozdz. VII, nr 3, s. 328.

${ }^{127}$ I Synod Diecezji Legnickiej, t. I, Statut Wyższego Seminarium Duchownego Diecezji Legnickiej, art. 67 § 2, s. 162.

${ }^{128}$ Por. Schema-tipo di regolamento, cap. IV, art. 18, nr 1. 


\section{Wnioski}

Z przeprowadzonych wywodów nasuwają się następujące wnioski:

1. W każdym wyższym seminarium duchownym, zarówno diecezjalnym jak i międzydiecezjalnym, powinna być biblioteka, jako konieczne narzędzie dla pracy naukowej profesorów i dla studiów alumnów.

2. Biblioteka seminarium duchownego należy do kategorii bibliotek kościelnych, czyli jest to uporządkowany zbiór rękopisów, druków lub opracowań i innych środków, mający na celu przekazywanie tekstów i obrazów, będący w posiadaniu wyższego seminarium duchownego.

3. W bibliotece seminaryjnej powinny znajdować się przede wszystkim dzieła z zakresu filozofii chrześcijańskiej, psychologii, nauk teologicznych oraz materiały konieczne do nauki języków obcych.

4. Biblioteka seminaryjna to nie tylko księgozbiór, ale również cała infrastruktura mająca służyć funkcjonowaniu biblioteki.

5. Odpowiedzialnymi za bibliotekę seminaryjną są biskup diecezjalny, rektor seminarium.

6. Bezpośrednim odpowiedzialnym i pierwszym pracownikiem biblioteki seminarium duchownego jest dyrektor biblioteki, którego mogą wspomagać inni pracownicy, zarówno etatowi, jak i wolontariusze.

Słowa kluczowe: biblioteka, biblioteka wyższego seminarium duchownego, prawo kanoniczne, księgozbiór, biskup diecezjalny, rektor seminarium, bibliotekarz

\section{THE LIBRARY OF THE THEOLOGICAL SEMINARY FROM LEGAL POINT OF VIEW}

\section{Summary}

This article presents the library of the theological seminary in canonical terms. The library of the seminary is an institution which collects, processes and offers readers the collections owned by the seminary.

The first part of this article shows the necessity for the seminary library. It then describes the collection of the seminary library, which should contain primarily works in the field of Christian philosophy, psychology, theological sciences and materials necessary for learning foreign languages. It is emphasized that the seminary library is not only a book collection, but also the entire infrastructure, the aim of which is to serve the functioning of the library.

The paper also presents those people who are in charge of the seminary library: a diocesan bishop, the rector of the seminary and a librarian, as well as other library staff, both full-time ones and volunteers.

Keywords: library, the library of theological seminary, canon law, book collection, diocesan bishop, the rector of the seminary, librarian 